
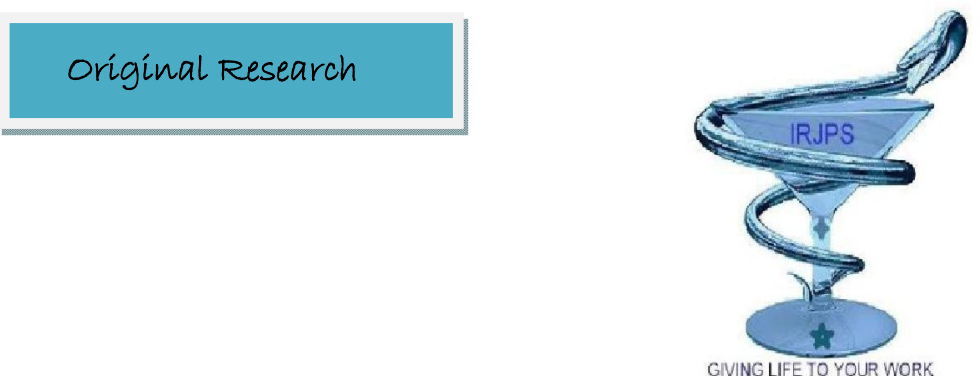

\title{
PHARMACOGNOSTICAL EVALUATION OF AERIAL PARTS OF IPOMOEA AQUATICA FORSK.
}

\author{
S. Deb ${ }^{* 1}$, U. Sharma ${ }^{1}$, S. Das ${ }^{2}$, A. Chowdhury ${ }^{3}$ \\ ${ }^{1}$ Institute of Pharmacy, Jalpaiguri, West Bengal, India \\ ${ }^{2}$ Calcutta Medical Collge and Hospital, Kolkata, West Bengal, India. \\ ${ }^{3}$ Department of Botany, University of North Bengal,Darjeeling, West Bengal.
}

Submitted on: 30.07.16; $\quad$ Revised on: 15.08.16; $\quad$ Accepted on: 18.08.16

\begin{abstract}
Ipomoea aquatic (Forsk), also known as water spinach, of Convolvulaceae family has been originated in China and distributed throughout India, Sri Lanka, Tropical Asia, Africa, and Australia. Ipomoea aquatic have been used in traditional medicine as a laxative, recommended for piles, and certain conditions with sleeplessness and head-ache while the plant has a calming effect. It is also supposed to possess an insulin-like activity according to indigenous medicine in Sri Lanka. No detailed work on pharmacognostic and development of quality parameters has been done on aerial parts of this plant specifically to determine the anatomical and other physicochemical standards required for its quality control. The present study deals with Pharmacognostic evaluation of leaves and aerial parts in terms of morphological, anatomical, quantitative microscopical examinations, including powder microscopy and physiochemical parameters including determination of different physical constants like ash values, extractive values etc. and also fluorescence analysis. The findings of the current study can be useful to progress and surge further scientific investigation on the leaves and aerial arts of this species and would be of immense use to identify and establish the authenticity of the plant Ipomoea aquatic Forsk.
\end{abstract}

KEY WORDS: Ipomoea aquatic Forsk., Convolvulaceae, Pharmacognostic study, Quality control

Corresponding Author: Soumya Deb

E-mail: debjoy.s@rediffmail.com
Indian Research Journal of Pharmacy and Science; 10(2016) 726-736

Journal Home Page: https://www.irjps.in 


\section{INTRODUCTION}

Pharmacognostic study is the preliminary step in the standardization of crude drugs. The detailed pharmacognostic evaluation gives valuable information regarding the morphology, microscopical and physical characteristics of the crude drugs. Pharmacognostic studies have been done on many important drugs, and the resulting observations have been incorporated in various pharmacopoeias [1]. There are a number of crude drugs where the plant source has not yet been scientifically identified. Hence pharmacognostic study gives the scientific information regarding the purity and quality of the plant drugs [2].

Ipomoea aquatic Forsk., the aquatic plant grows wild and is cultivated throughout Southeast Asia and is usually consumed as a green leafy vegetable in the region [3]. It is edible, semiaquatic, herbaceous, vegetable plant and used in traditional medicine as a laxative, recommended for piles, sleeplessness and head-ache.[4],[5]. Water spinach is also supposed to possess an insulin-like activity according to indigenous medicine in Sri Lanka [6].

Ipomoea aquatic Forsk is also considered a tonic as the species contains several vitamins, including A, B, $\mathrm{C}$, E, and "U" (S-methyl-methionine) [7]. The species also contains aliphatic pyrrolidine amides, hentriacontane, $\beta$-sitosterol and its glycosides, prostaglandin, leukotrine, N-trans- and Ncisferuloyltyramines [8][9].

Detailed Pharmacognostic and preliminary phytochemical studies have not been reported for the leaves and aerial part of this plant. Therefore the main aim of the present study was to Pharmacognostical investigation such as organoleptic, morphologic, microscopic and other applicable physico - chemical parameters of leaves and aerial parts of Ipomoea aquatic Forsk. which could be used to prepare a monograph for the proper identification of the plant.

\section{MATERIALS AND METHODS}

\section{Collection and authentication of the plant:}

Whole plants were collected from the pond side of Cooch Behar, North Bengal and authenticated by Dr.
A. P. Das, Professor and Head of Taxonomy and environmental botany and Herbarium- in-charge, The North Bengal University, Darjeeling. A herbarium was deposited in the Department of botany with accession no. 09696, dated the $20^{\text {th }}$ May2013 in The North Bengal University, Darjeeling.

\section{Morphological studies:}

Morphological characters of fresh leaves and stems were examined properly. The following macroscopic characters for the fresh leaves were noted: size and shape, color, surfaces, venation, presence or absence of petiole, the apex, margin, base, lamina, texture, odor and taste. Also different characters like nodes, internodes, different buds, surface including colour and odour of stem was studied [10,11].

\section{Microscopic Studies:}

The outer epidermal membranous layer (in fragments) of both surface of fresh leaf were cleared in chloral hydrate, mounted with glycerin and observed under a compound microscope. The presence, types and distribution of stomata and epidermal cell was observed. Stomatal number, stomatal index, vein- islet number and veinlet termination number of fresh leaves were determined by using camera Lucida and stage micrometer. Transverse section of the leaf and stem were also cleared, mounted, stained and observed [12].

\section{Powder microscopy:}

The leaves were shade dried and powdered using mechanical grinder for powder analysis. Small amount of powdered drug mounted on slide and treated it with Phloroglucinol in $\mathrm{HCl}$ and iodine solution to clear the view and watch under the microscope to know about its powdered characters.

\section{Fluorescence analysis:}

The fluorescence character $\mathrm{s}$ of the plant material in different solvents observed using visible, short UV and long UV light [13]. Alcohols, mineral acids in different concentrations, halogens and other various chemical and organic reagents used to perform fluorescence analysis [14].

Physicochemical analysis:

The physicochemical characteristics of powdered leaf were determined as per WHO guidelines [15]. 
Various physicochemical parameters like LOD, ash values (total ash, acid insoluble ash, water soluble ash, sulphated ash), extractive values (aqueous, chloroform, ethanol, methanol), swelling index and foaming index of the powdered materials were established [16, 17].

\section{RESULTS:}

\section{Morphological characters:}

Ipomoea aquatica (Forsk) is a vascular, glabrous, semi-aquatic trailing vine with milky sap, grows in water or floating on water, native to tropics and subtropics that grow wild and sometime cultivated. Water spinach is an herbaceous perennial plant belonging to the family Convolvulaceae. It has 2-3 meters (7-10 ft.) or more long hollow and viny stem, grow prostrate or floating in aquatic situations and the roots are produced from the nodes and penetrate into wet soil or mud. Leaves are alternate, simple, with glabrous petioles $3-14 \mathrm{~cm}$ (1-6 in) long. Leaf shape varies from typically sagittate (arrow headshaped) to lanceolate, $5-15$ centimeters (2-6 in) long and $2-8$ centimeters $(0.8-3$ in) broad. The margins entire or angular, and sub lobed, surface glabrous or rarely pilose. Peduncles are erect, 2.5 to 5 centimeters long, with 1 or 2 flowers, borne in the axils of the leaves. Sepals are green, oblong, about 8 millimeters long. Corolla is narrowly bell-shaped, about 5 centimeters long, and purplish; limb nearly white or pale pink purple, about 5 centimeters in diameter, the tube deeper purple inside (Fig.1).Detail of morphological characters of leaves and stems has been mentioned (Table.1 and table.2).

\section{Microscopical characters:}

Under microscope, the stomata were found distributed on both abaxial surface and adaxial surface. Both the surface characteristically contains Paracytic stomata (Fig.2).Stomatal density is more in upper epidermis than lower epidermis. Frequent vein islet and vein terminals are observed in upper surface (Table.3).

The unicellular covering trichomes are observed on both surfaces, more frequent on upper surface of midrib portion. Transverse section through midrib with lamina in both side revealed the dorsiventral character of the leaf. The transverse section of leaf exposed a layer of epidermis composed of compact rectangular cells as outermost covering on both upper and lower layer. The upper epidermis was enveloped with deposition of cuticle. In lamina portion a double layer of large, elongated, compact, chlorophyll containing palisade parenchyma underneath the upper epidermis occupying more than one third portion of the mesophyll tissue was found. Remaining portion of mesophyll was occupied by few layers of spongy parenchyma with large intercellular spaces. In midrib portion, epidermis was followed by few layers of collenchymatous hypodermis in continuation with few layers of parenchyma cells. Xylem and phloem portion of vascular bundle consist of their basic elements. Starch granules found to be present in midrib portion.(Fig.3).

Transverse section of the stem is round in shape, glabrous and contains a large hollow pith in the center. Cortex portion is thick and consists of Exodermis, Hypodermis(collenchyma) and Endodermis (parenchyma) layers. Large numbers of vascular bundles are arranged in a concentric ring with pericycle. Xylem vessels appear prominent and large followed by phloem in each vascular bundle which is capped by sclerenchyma fiber. Few starch grains are also foundin both below and above the vascularbundle ring(Fig.4, 5).

\section{Powder microscopy:}

Powder of the herb is fine, greyish green, fibrous, tasteless and odourless. When stained with phloroglucinol in sulphuric acid and iodine solution separately and observed under microscopic observation, powder of the herb shows presence of epidermis (cells with thin, slightly sinuous walls), long unicellular uniseriate covering trichomes, paracytic stomata, prism crystals of calcium oxalate, oil cells, phloem fibers etc. (Fig.6-Fig.13).

\section{Fluorescence analysis:}

The fluorescence characters of the powdered plant material in different solvents like Alcohols, mineral acids in different concentrations, halogens and other various chemical and organic reagents observed using visible, short UV and long UV light and mentioned (table.4).

\section{Physicochemical analysis:}

Various physicochemical parameters of powdered leaves like ash values viz., total ash, acid insoluble 
ash, water soluble ash and sulphated ash; extractive values viz., alcohol soluble extractive value, water soluble extractive value, methanol soluble extractive value and chloroform soluble extractive values; loss on drying, swelling index and foaming index were calculated and recorded as per WHO guidelines (Tab.5).

Table.1: Morphological characters of leaf

\begin{tabular}{|c|c|c|}
\hline Sl no. & Particulars & Observation \\
\hline 1 & Colour & Green \\
\hline 2 & Odour & No \\
\hline 3 & Taste & $5.0-15.0 \mathrm{~cm}$. \\
\hline 4 & Length & Entire \\
\hline 5 & Margin & Acute \\
\hline 6 & Apex & Symmetric,petiolate. \\
\hline 7 & Base & Glabrous-pilose. \\
\hline 8 & Surface & Sagittate. \\
\hline 9 & Shape & Reticulate. \\
\hline 10 & Vein & Absent. \\
\hline 11 & Stipules & Simple \\
\hline 12 & Type & One \\
\hline 13 & Main nerves & Present \\
\hline 14 & Petioles & \\
\hline
\end{tabular}

Table.2: Morphological characters of stem

\begin{tabular}{|c|c|c|}
\hline Sl no. & Particulars & Observation \\
\hline 1 & Colour & Green \\
\hline 2 & Odour & No \\
\hline 3 & Taste & Pubescent. \\
\hline 4 & Surface & $\begin{array}{c}\text { Possess appendages, i. e. leaves, } \\
\text { branches and flowers. }\end{array}$ \\
\hline 5 & Nodes & $2-2.5$ cm long, hollow. \\
\hline 6 & Internodes & $\begin{array}{c}\text { Present in the axis of leaves on the } \\
\text { stem. }\end{array}$ \\
\hline 7 & Axillary buds & Absent \\
\hline 8 & Lenticels & Absent \\
\hline 9 & Leaf scar & Present \\
\hline 10 & Terminal buds & Present \\
\hline 11 & Flower buds &
\end{tabular}

Table.3: Quantitative analytical microscopical parameter (leaf constants) of leaves

\begin{tabular}{|c|c|c|}
\hline S1 no. & Parameters & Values obtained \\
\hline 1 & Stomatal no. in upper epidermis & $305 / \mathrm{square} \mathrm{mm}$ \\
\hline 2 & Stomatal no. in lower epidermis & $375 / \mathrm{square} \mathrm{mm}$ \\
\hline
\end{tabular}




\begin{tabular}{|c|c|c|}
\hline 3 & Stomatal index in upper epidermis & 14.78 \\
\hline 4 & Stomatal index in lower epidermis & 17.16 \\
\hline 5 & Palisade ratio in upper epidermis & 7.24 \\
\hline 6 & Vein-islet no. in upper epidermis & $40.66 /$ square $\mathrm{mm}$ \\
\hline 7 & Vein termination no. in upper epidermis & $25.33 /$ square $\mathrm{mm}$ \\
\hline
\end{tabular}

Table.4: Fluorescence Study

\begin{tabular}{|l|l|l|l|}
\hline \multicolumn{1}{|c|}{ Powdered drug } & \multicolumn{1}{c|}{ Visible light } & \multicolumn{1}{c|}{ UV light(short) } & \multicolumn{1}{c|}{ UV light(long) } \\
\hline Powder & Green & Greenish brown & Greenish brown \\
\hline Powder $+5 \% \mathrm{FeCl}_{3}$ & Deep green & Green & Black brown \\
\hline Powder $+1 \mathrm{~N} \mathrm{HCl}$ & Pale green & Green & Brown \\
\hline Powder $+1 \mathrm{~N} \mathrm{HNO}_{3}$ & Reddish brown & Green & Brown \\
\hline $\begin{array}{l}\text { Powder }+10 \% \\
\mathrm{~K}_{2} \mathrm{Cr}_{2} \mathrm{O}_{7}\end{array}$ & Reddish & Green & Brown black \\
\hline Powder $+1 \mathrm{M} \mathrm{NaOH}$ & Green & Reddish green & Red \\
\hline Powder $+\mathrm{AgNO}_{3}$ & Green & Greenish brown & Light brown \\
\hline Powder $+\mathrm{Ammonia}$ & Citrine green & Greenish black & Brown \\
\hline Powder $+1 \mathrm{~N} \mathrm{H}_{2} \mathrm{SO}_{4}$ & Green & Green & Brown black \\
\hline Powder $+\mathrm{Br}_{2}$ water & Reddish green & Brown & Light brown \\
\hline Powder $+5 \% \mathrm{H}_{2} \mathrm{O}_{2}$ & Pale green & Green & Brown \\
\hline Powder $+\mathrm{CCl}_{4}$ & Green & Green & Greenish brown \\
\hline Powder $+\mathrm{Methanol}$ & Green & Brown & Dark brown \\
\hline Powder $+\mathrm{CH}_{3} \mathrm{COOH}$ & Green & Reddish brown & Dark brown \\
\hline Powder $+\mathrm{Xylene}$ & Greyish green & Grey & Orange \\
\hline Powder $+5 \% \mathrm{KOH}$ & Cascade green & Reddish brown & Dark brown \\
\hline Powder $+\mathrm{I}_{2}$ & Reddish green & Brown & Dark brown \\
\hline
\end{tabular}

Table.5: Physiochemical analysis

\begin{tabular}{|c|l|c|}
\hline $\begin{array}{c}\text { Sl. } \\
\text { No. }\end{array}$ & \multicolumn{1}{|c|}{ Particulars } & Result $(\% \mathrm{w} / \mathrm{w})$ \\
\hline 1 & Loss on drying & 4.30 \\
\hline 2 & Total ash & 9.90 \\
\hline 3 & Water soluble ash & 1.75 \\
\hline 4 & Acid insoluble ash & 6.50 \\
\hline 5 & Water soluble extractive value & 42.31 \\
\hline 6 & Chloroform soluble extractive value & 5.98 \\
\hline 7 & Ethanolic extractive value & 30.07 \\
\hline 8 & Methanolic extractive value & 35.15 \\
\hline 9 & Swelling index & 25.63 \\
\hline 10 & Foaming index & 16.42 \\
\hline
\end{tabular}




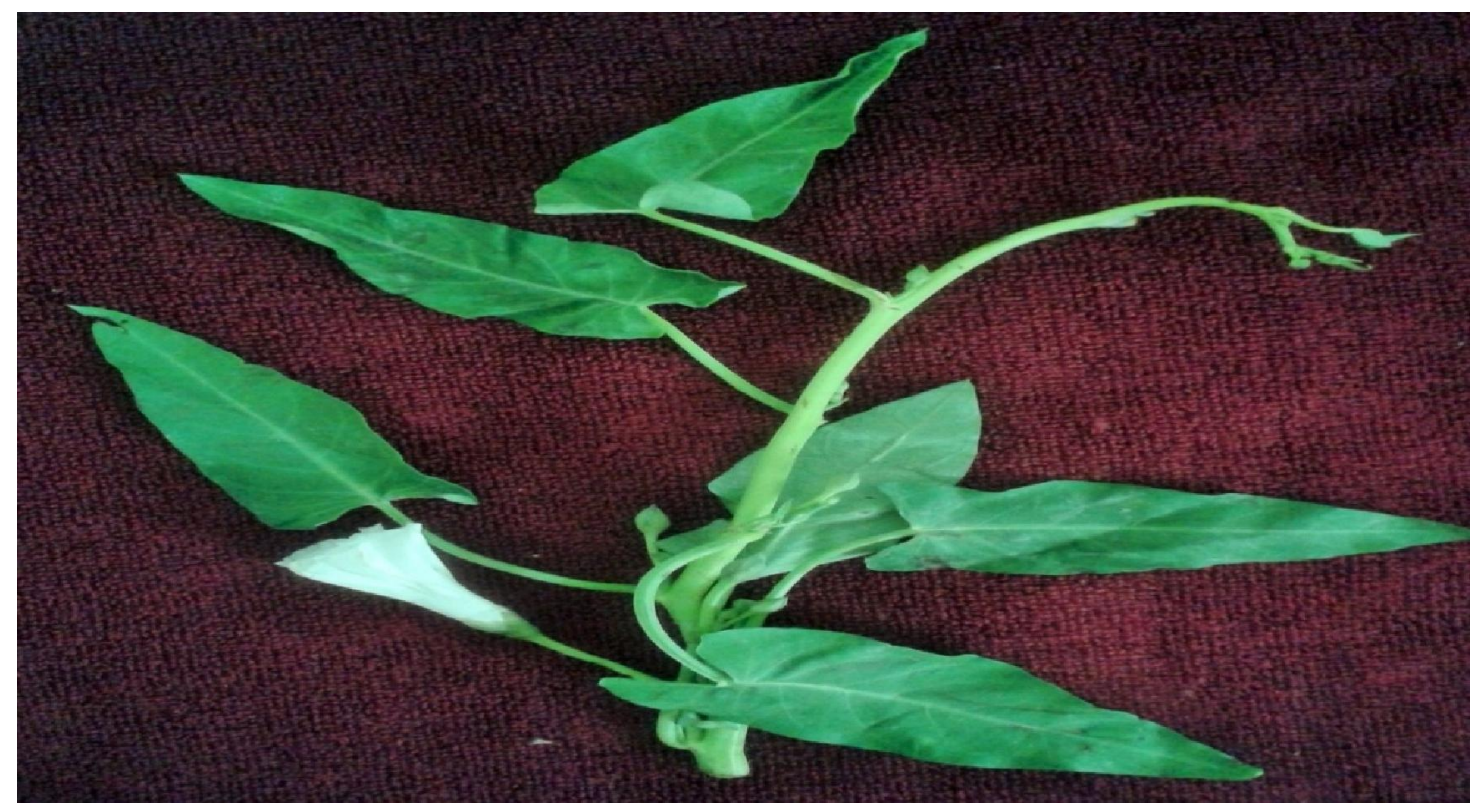

Fig.1: Leaves and aerial parts of Ipomoea aquatica Forsk.

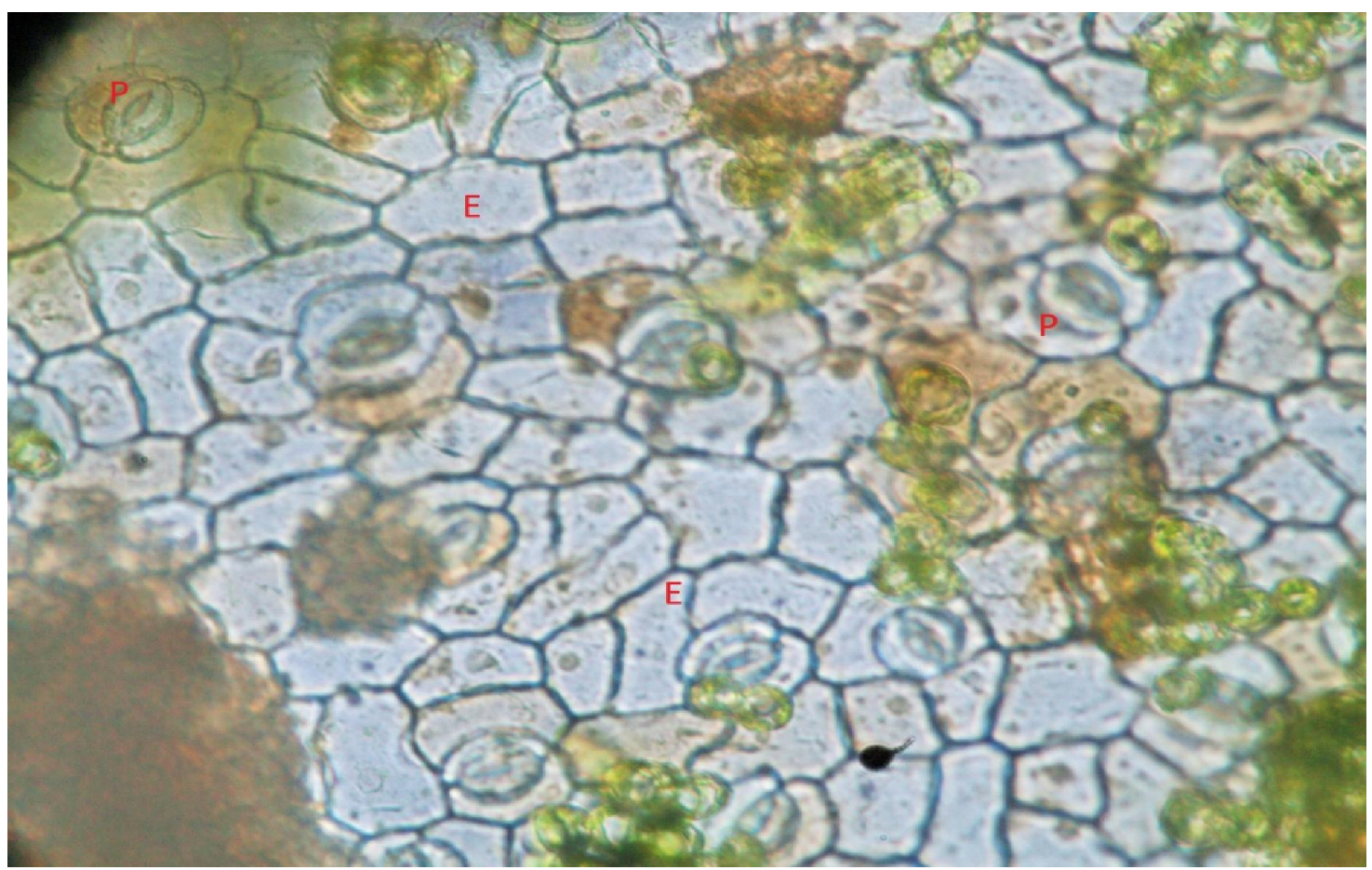

Fig.2: Paracytic stomata in upper surface of Ipomoea aquatica; P: Paracytic stomata, E: Epidermal cells 


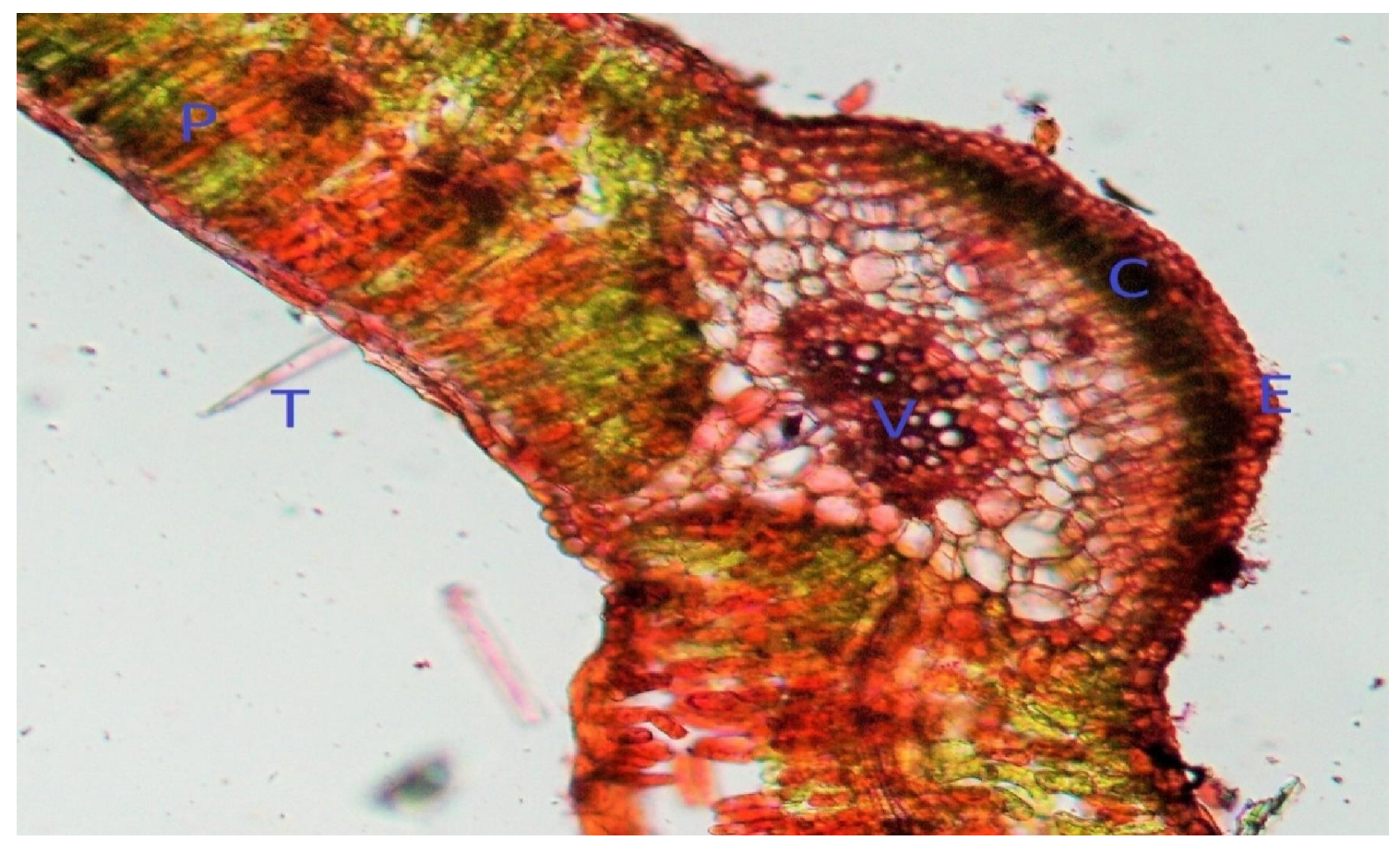

Fig.3: T.S. of Ipomoea aquatica leaf; T: Trichome, P: Palisade cells, V: Vascular bundle, C: Collenchyma, E: Epidermis

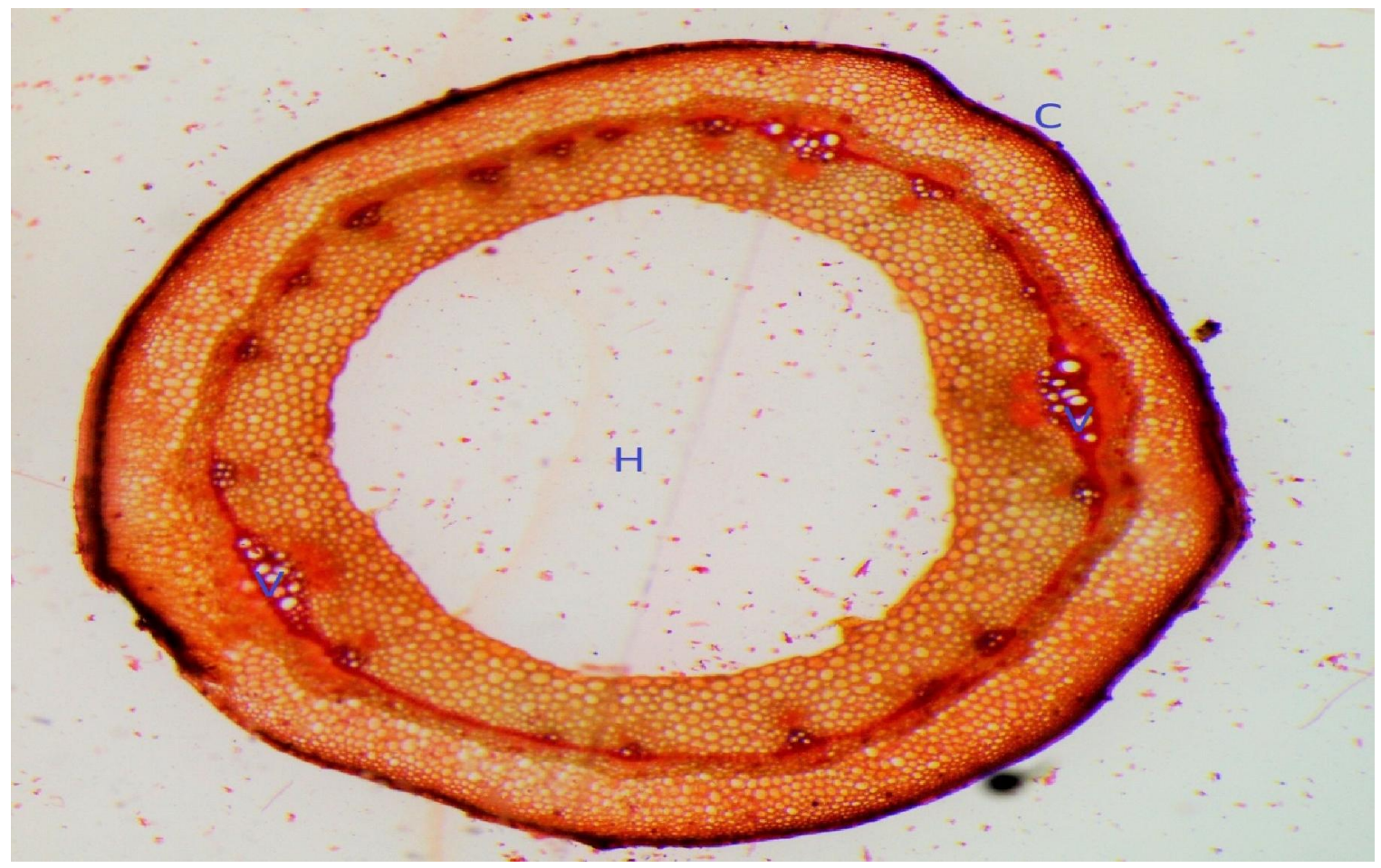

Fig.4: T.S. of Ipomoea aquatica stem; H: Hollow pith, C: Cortex, V: Vascular bundle 


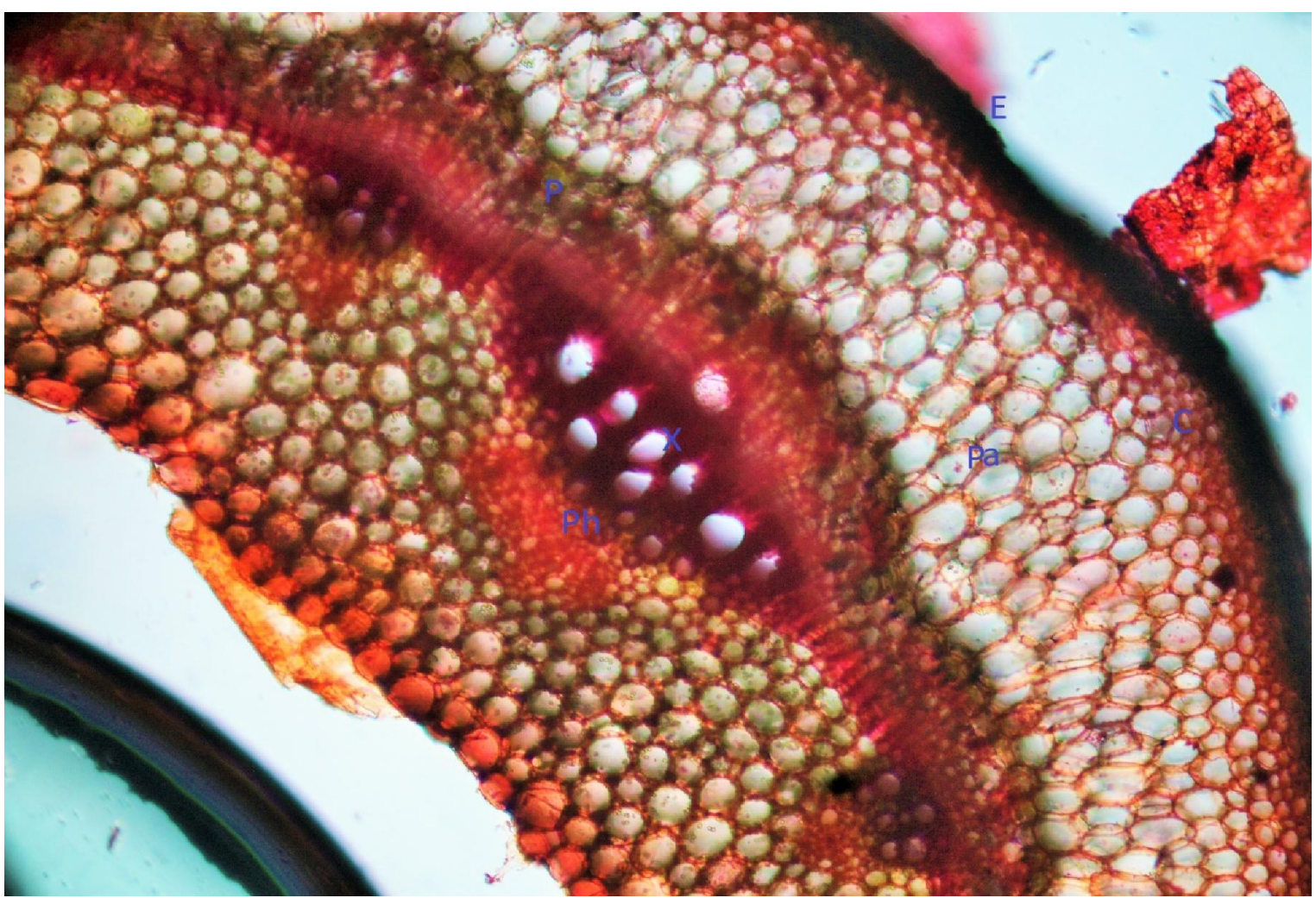

Fig.5: T.S. of stem of Ipomoea aquatica; E: Exodermis, Pa: Parenchyma, C: Collenchyma, X: Xylem vessele, P: Pericycle, Ph: Phloem

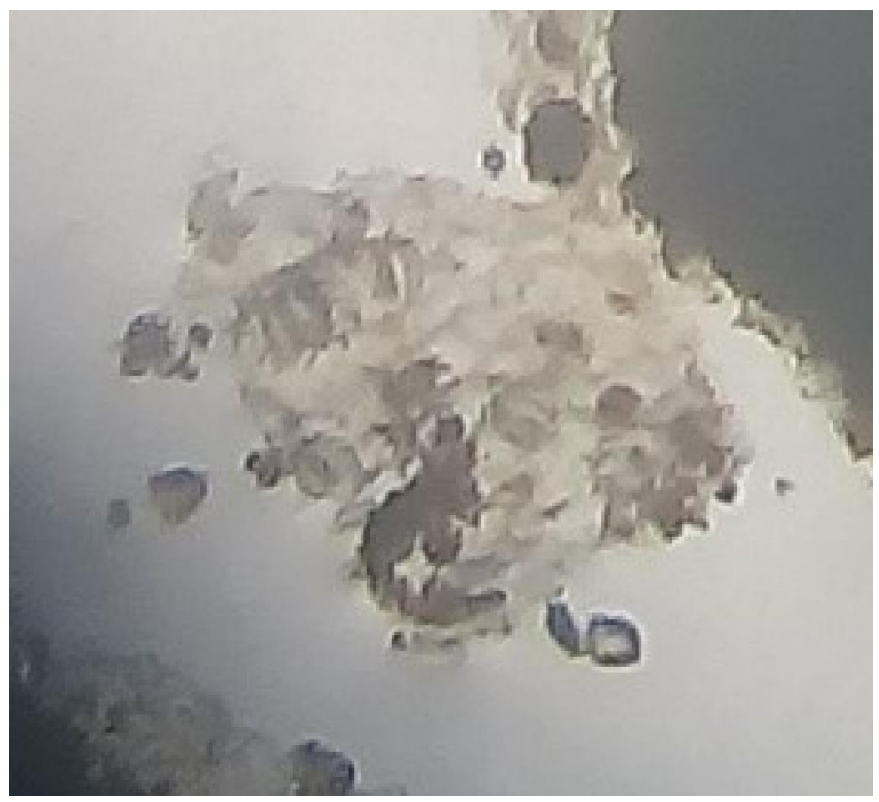

Fig.6: Powder microscopy: Epidermal cells 


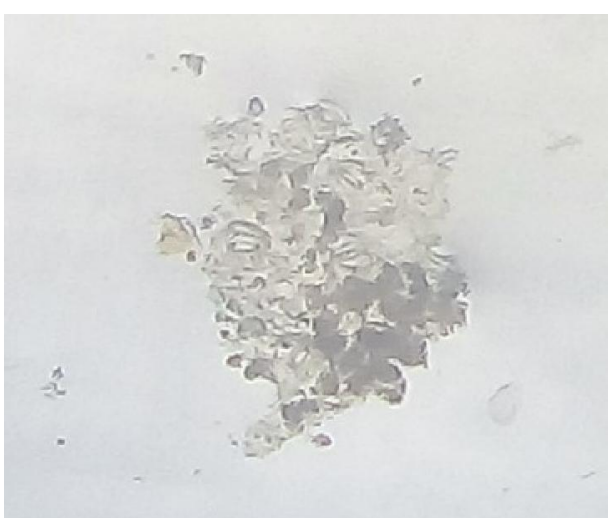

Fig 7: Powder microscopy: stomata

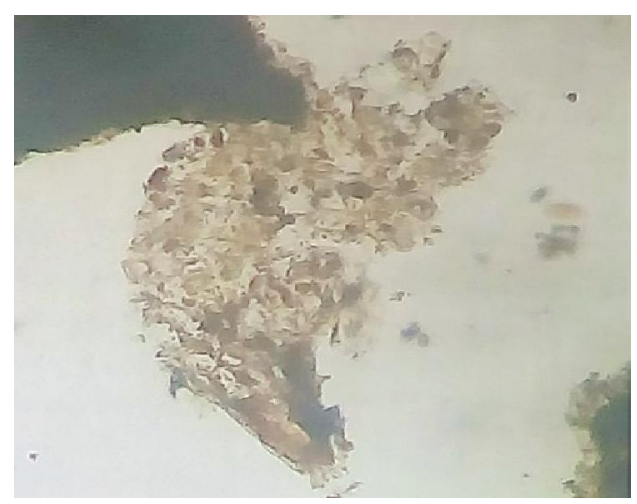

Fig.8: Powder microscopy: Laticiferous cells

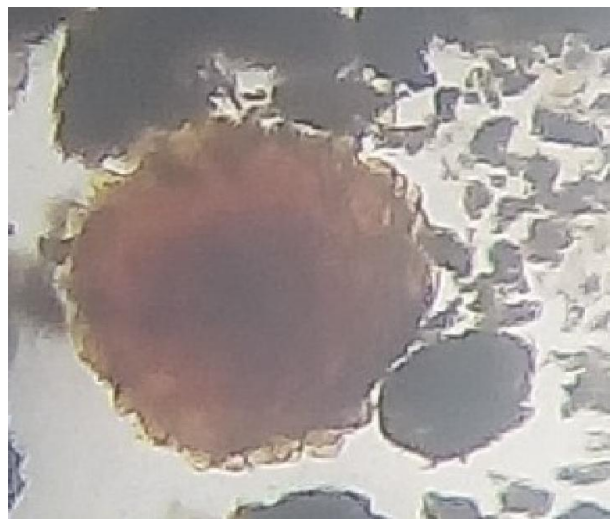

Fig.9: Powder microscopy: volatile oil cell

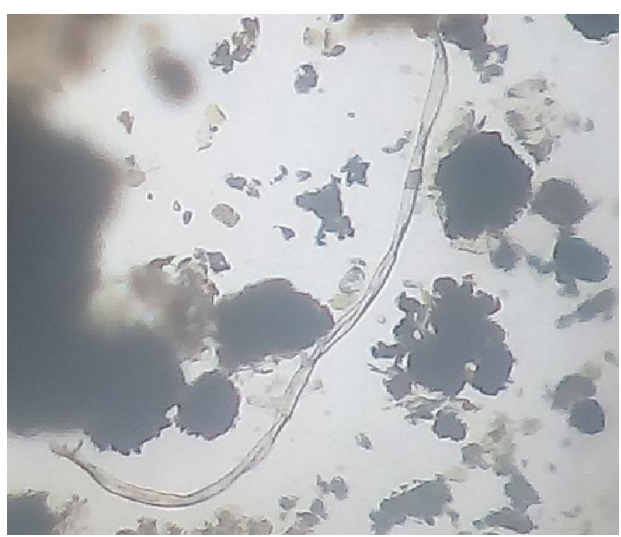

Fig.10: Powder microscopy: Phloem fibre

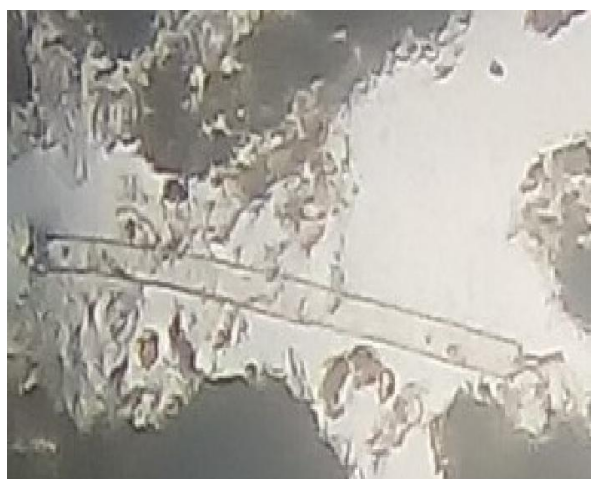

Fig.11: Powder microscopy: Annular vessels

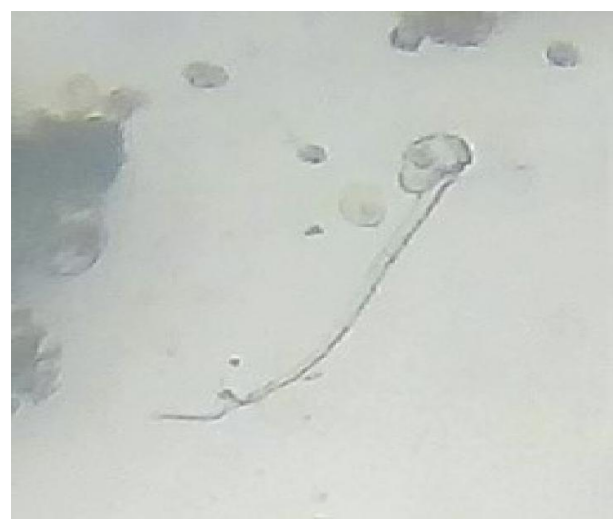

Fig.12: Powder microscopy: Unicellulartrichome

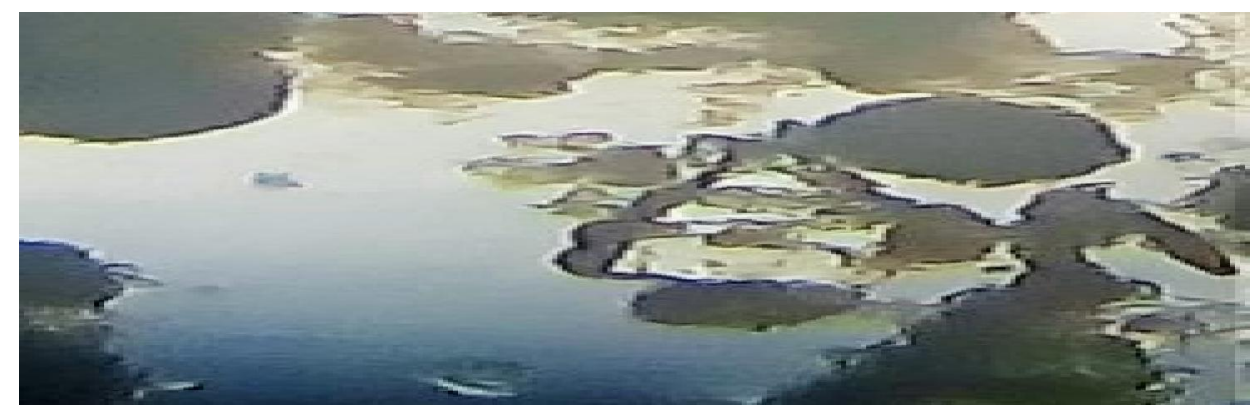

Fig.13: Powder microscopy: calcium oxalate 


\section{DISCUSSIONS}

In the present investigation, the detailed pharmacognostic account of Ipomoea aquatic Forsk is given which includes macroscopic and microscopic characters with leaf constants, which will be helpful for the correct botanical identification of the drug. Leaves of Ipomoea aquatic Forsk possess unicellular covering and glandular trichomes on both epidermises, contains paracyticstomata in same as well as in both surfaces which are comparatively more on lower epidermis.Prisms of calcium oxalate, oil cells and phloem fibers found in powder microscopy. Ash values, extractive values and fluorescence analysis can be used as reliable aid for detecting adulteration. The extractive values confirmed the presence of more amount of polar or water soluble phyto constituents, ash values representing the presence of more water soluble inorganic salts, swelling index and foaming index result reflects the presence of considerable amount of mucilaginous substances and saponins.

\section{CONCLUSION}

The evaluation of a crude drug is an integral part of establishing the correct identification of a plant material. For this the pharmacognostic evalution can provide useful information for identification and authentication of plant. The pharmacognostic

\section{REFERENCES}

1. Rajan M, Kumar VK, Kumar PS, Venkatachalam T, Anbarasan V., Pharmacognostical and Phytochemical Studies of the Leaves of Albizia Odoratissima (L.F) Benth. International Journal of Pharmacognosy and Phytochemical Research 2011;3(3): 47-55.

2. Dhanabal SP, Suresh B, Sheeja E, Edwin E, Pharmacognostical studies on Passiflora quadrangularis., Indian Journal of Natural Products., 2005; 21(1): 9-11.

3. Huang DJ, ChenHJ, LIN CD, Lin YH., Antioxidant and antiproliferative activities of water spinach (Ipomoea aquaticaForsk) standard for the aerial parts of Ipomoea aquatic Forsk.is laid down in this study. It can serve as an important source of information to ascertain the identity and to determine the quality and purity of the plant material in future studies. To conclude, this study could be used as a diagnostic tool for the standardization of this medicinal plant and will helpful in characterization of crude drug.

\section{ACKNOWLEDGEMENT}

Authors are thankful toDr. A. P. Das, Professor and Head of Taxonomy and environmental botany and Herbarium- in-charge, The North Bengal University, Darjeeling and Pharmacognosy laboratory, Institute of Pharmacy, Jalpaiguri under The West Bengal University of Health Sciences, Kolkata, W.B. for providing facilities and providing continuous support to carry out this type of research work successfully.

\section{AUTHORS CONTRIBUTION}

S. Deb carried out the pharmacognostic studies, participated in the sequence alignment and drafted the manuscript. A. Chowdhury carried out the photographic investigations. S. Das participated in the design of the study. U.Sharma conceived of the study, and participated in its design and coordination and helped to draft the manuscript. All authors read and approved the final manuscript.

constituent., Bot. Bull. Acad. Sin., 2005; 46: 99-106.

4. H. Burkill., A Dictionary of the Economic Products of the Malay Peninsula. Ministry of Agriculture and Cooperatives., Kuala Lumpur,1966.

5. Van-Valkenburg JLCH, Bunyapraphatsara N., Plant Resources in South-East Asia., Number 12 Backhuys Publishers, Leiden, The Netherlands.2001.

6. Malalavidhane TS, Wickramasinghe S, Perera MSA, Jansz ER., Oral hypoglycaemic activity of Ipomoea aquatica 
in streptozotocin-induced diabetic wistar rats and Type II diabetics., Phytother.

Res., 2003;17: 1098-1100.

7. WestphalE.,Ipomoea aquaticaForsk.in Plant Resources in South-East Asia.,Pudoc Scientific Publishers., 1993; 181-84.

8. Bruemmer JH, Roe R., Protein extraction from water spinach (Ipomoea aquatica), Proceedings of the Florida State Horticultural Society, Florida., 1979; 72: $140-43$.

9. Snyder GH, Morton JF, Gentung WG., Trials of Ipomoea aquatica, nutritious vegetable with high protein-and nitrateextraction potential., Proceedings of the Florida State Horticultural Society, 1981;94: 230-235.

10. Wallis TE.,Textbook of Pharmacognosy., Delhi : CBS Publishers; 1985, 572-575.

11. Trease GE, Evans WC., Trease and Evans Pharmacognosy. London: WB Saunders Ltd; 1996, edi: 14, p 119-159.
12. African Pharmacopoea. General methods for Analysis. Lagos: OAU/ STRC Scientific Publications; 1986, edi: 2(2), p 1-5, 137149, 223-237.

13. Mukherjee PK. Quality control of herbal drug. New Delhi: Business Horizons Pharmaceutical Publishers; 2010, edi:1, p 184-191.

14. Kokate C K, Gokhale S B. Purohit A P.,Practical Pharmacognosy. New Delhi, Vallabh Prakashan; 1994, edi:3, p 115-127.

15. WHO. Quality control methods for medicinal plant material. Geneva: Organisation Mondiale De La Sante.1992; 22-34.

16. Kay LA. Microscopical studies of Drugs. London :Bailliere Tindal and Co; 1938, edi:1, p 17-18.

17. Johansen DA. Plant Micro technique. New York : McGraw Hill Book Co; 1940, edi:1, p 523. 